\title{
Kontestasi Sistem Ekonomi Islam dan Konvensional
}

\author{
Rusdin Muhalling \\ Fakultas Ekonomi dan Bisnis Islam IAIN Kendari \\ Email: rusdinmuhalling02@gmail.com
}

\begin{abstract}
Economic Thought emerged since the presence of human beings on earth, This thinking is a reaction to the empirical dynamics in all aspects of human life. Fairness is a recognition and equal treatment between rights and obligations. Based on ethical awareness, humans are required to demand not just rights and to forget obligations. If it only demands rights and carries obligations, then its attitudes and actions will tend to lead to extortion and enslavement of others.

Conversely, if a human only performs obligations and forgets to claim his rights, it will be easily blackmailed by others. For example, employer and employer relations, traders and buyers, etc., then it is necessary to understand a fair understanding, so that each knows its role where the rights and where the obligations. That way, they can put themselves in the right position. If it can be understood together then the so-called harmony and harmony will be created. Although many theories hold that injustice is the logical consequence of a system that applies whether economically, socially, or politically in a society.
\end{abstract}

Key words: Diversity, economic system.

\begin{abstract}
Abstrak
Pemikiran Ekonomi muncul semenjak kehadiran manusia di bumi, Pemikiran ini merupakan reaksi terhadap dinamika empirik dalam segala aspek kehidupan manusia.Keadilan merupakan pengakuan dan perlakuan yang seimbang antara hak dan kewajiban. Berdasarkan kesadaran etis, manusia dituntut untuk tidak hanya menuntut hak dan melupakan kewajiban. Jika hanya menuntut hak dan melupkan kewajiban, maka sikap dan tindakannya akan cenderung mengarah kepada pemerasan dan memperbudak orang lain.

Sebaliknya, jika manusia hanya menjalankan kewajiban dan lupa menuntut haknya, maka akan mudah diperas oleh orang lain. Misalnya, hubungan majikan dan buruh, pedagang dan pembeli, dan sebagainya, maka sebaiknya perlu memahami pengertian adil, sehingga masing-masing tahu peranannya mana hak dan mana kewajiban. Dengan begitu, mereka dapat menempatkan dirinya masing-masing pada posisi yang benar. Jika hal itu dapat dipahami bersama maka yang dinamakan keseibangan dan keharmonisan akan tercipta. Walaupun banyak teori yang menyatakan bahwa ketidakadilan merupakan akibat logis dari suatu sistem yang berlaku baik ekonomi,sosial, ataupun politik dalam suatu masyarakat.
\end{abstract}

Kata Kunci: Keragaman, sistem ekonomi. 


\section{A. Pendahuluan}

Semua sistem ekonomi yang ada saat ini, berkeinginan untuk memberikan solusi yang terbaik terhadap permasalahan sosial ekonomi, baik terhadap sistem ekonomi kapitalis, sosialis dan Islam. Akan menjanjikan sistem ekonomi yang berkeadilan dan menuju pada suatu kemakmuran. Namu tujuan dari ketiga sistem terseut sangat berbeda. Jika disisi lain mekanisme yang menjembatani sistem konglomerasi dan monopoli, maka seberapa besarkah efektifitas sistem ekonomi sosialis menuju perekonomian yang sejahtera (Karim, 2013: 31-32).

Cita-cita sosial Islam dimulai dengan menumbuhkan aspek-aspek aqidah dan etika dalam diri penganutnya. Hal ini dimulai dengan pendidikan kejiwaan (hati) bagi setiap pribadi, keluarga dan masyarakat. Sehingga yang pada akhirnya terciptalah hubungan yang serasi antara seluruh anggota masyarakat dalam mewujudkan ksejahteraan lahiriah dan batiniah. Cita-cita sosial Islam dapat diwujudkan dengan menggerakkan roda perekonomian yang berkeadilan sosial di atas perinsip-prinsip syariah (Shihab, 2002: 242).

Kegiatan ekonomi atau bisnis dalam dunia perdagangan merupakan salah satu usaha yang sangat mulia dan penting dalam kehidupan umat manusia, sehingga menarik untuk diungkap, dimana Al-Qur'an telah mengajak kepada umat manusia untuk mengmalakannya, yang sesuai dengan penerapan perinsip-perinsip ekonomi dalam segala aspek yaitu aqidah,syariah dan akhlak. Hubungan ekonomi secara harmonis jika terjadi hubungan timbale-balik yang dilandasi dengan kualitas akhlak (Shihab, 2002: 237).

Hubungan harmonis dalam penerapan prinsi-prinsip ekonomi Islam telah diisyaratkan dalam alQur'an, antara lain: dengan menjauhi kecurigaan antara pelaku ekonomi, misalnya dalam utang piutang dijelaskan hendaklah ditulis transaksinya: janganlah kamu jenu menulis utang itu, baik kecil maupun besar, sampai batas waktu pembayarannya, Q.S: 2/282. Maka keragaman sistem ekonomi yang terjadi turut mempengaruhi pola pikir, 
dan pelaku konsumen sehingga prinsip-prinsip ekonomi Islam yang berisi motivasi dalam kegiatan ekonomi, dimana Islam mengajarkan agar aktifitas ekonomi dilakukan atas dasar motivasi impersonal yang berdimensi ibadah yang dapat dijalin melalui hubungan kerjasama dengan dengan motifasi keikhlasan dan kejujuran (Ramli, 1997).

\section{B. Ragam Sistem Ekonomi}

Sistem ekonomi dunia saat ini masih dikusai oleh Ekonomi Kapitalis dan Sosialis. Dalam konteks ekonomi, sistem ini menujukkan dan telah mampu meningkatkan kemakmuran pada rakyatnya. Kedua sistem ini diambil sebagai bahan rujukan di berbagai negara di dunia termasuk Indonesia. Sistem ini sangat dipengaruhi oleh kondisi negara itu sendiri, demikian pula halnya sistem ekonimo sosialis, yang berkembang di Rusia dan China. Sementara sistem ekonomi Islam yang diilhami oleh alQur'an dan Hadis, yang memiliki karakter sendiri. Sistem ekonomi Islam merupakan implementasi dari tanggungjawab manusia kepada Allah swt. sehingga aktifitas ekonomi oleh kaum muslimin didasarkan pada prinsip tauhid, syariah dan akhlak. Hakikatnya ketiga sistem (kapitalis, sosialis dan Islam) ekonomi bertujuan untuk mewujudkan keadilan sosial ekonomi serta kemakmuran masyarakat.Sehingga amat penting untuk dikaji, bahwa selama ini sistem kapitalis dan sosialis telah gagal mewujudkan tujuan sosial bagi masyarakat. Sehingga perlu diungkap perbedaan dari ketiga sistem tersebut secara mendalam dan objektif (Sudarsono, 2002: 73 dan 78).

\section{Sistem Ekonomi Kapitalis}

Ekonomi kapitalis sangat dipengaruhi oleh semangat mendapatkan keuntungan semaksimal mungkin dengan sumberdaya yang terbatas. Usaha kapitalis ini didukung oleh nilai-nilai kebebasan untuk memenuhi kebutuhannya. Pemahaman ini didasari oleh filosofi Adam Smith, bahwa terselenggaranya keseimbangan pasar disebabkan oleh karena manusia mementingkan kepentingan pribadi.Kapitalisme telah mengakui bahwa kebebasan manusia tidak bisa bebas lepas, tetapi kebebasan manusia 
terbatas yang dibatasi oleh kebebasan orang lain. Kebebasan ini menjadi ajaran universal dalam masyarakat Kapitalis. Norma kapitalis berdasarkan bahwa kebebasan kita di batasi oleh kebebasan orang lain. Maka norma merupakan konsensus /aturan bersama (Sudarsono, 2002: 79-80).

Sistem ekonomi Kapitalisme mempunyai kecenderungan, antara lain: pertama, Kebebasan memiliki harta perorangan. Negara menjamin kebebasan masyarakat untuk memiliki hartanya dan mempergunakannya. Setiap usaha yang dipergunakan sesuai dengan kepentingan yang diperbolehkan asal tidak mengganggu ketentuan negara. Segala sesuatu yang mampu digunakan dalam mendapatkan harta menjadi unsur penting dalam sistem kapitalis, utamanya di bidang ekspoloitasi factor-faktor produksi. Dialektika kehidupan kapitalis mendorong sikap mementingkan diri sendiri.

Kedua, kebebasan ekonomi dan persaingan bebas. Sistem kapitalis membatasi usaha-usaha monopoli yang cenderung mengganggu mekanisme pasar, hal ini dilakukan untuk menjaga terjadinya kesinambungan dalam perekonomian. Hal ini dilakukan sebab monopoli menyebabkan harga barang tinggi serta dapat menekan pemerintah untuk mendukung posisi pasar monopolistic. Sistem kapitalis juga membuka lebar persaingan pasar, asumsi dasarnya adalah bawa persaingan bebas merupakan syarat bagi pemberdayaan di berbagai sector ekonomi, sehingga tercipta efisiensi ekonomi. Namun disadari bahwa dengan persaingan bebar, maka kehidupan semakin renggang oleh masalah sosial, dekadensi moral, diskriminasi dan sebagainya.

Ketiga, ketimpangan ekonomi. Kebebasan dan persaingan bebas mengakibatkan sumber-sumber produksi hanya dimiliki oleh pengusaha yang bermodal besar, para buruh/pekerja dipergunakan sebagai alat produksi yang bekerja maksimal mengejar keuntungan finansial pengusaha. Sehingga ketimpangan ekonomi terjadi antara pengusaha dan pekerja, dimana pengusaha memebrikan jasa/upah pada pekerja sesuai volume produksi, sehingga pekerja bukan sebagai mitra 
pengusaha, tetapi sebagai mesin dari proses produksi (Sudarsono, 2002: 7982).

Sistem ekonomi kapitalis tidak seluruhnya berekses negatif terhadap perekonomian, di sisi lain sistem kapitalis memiliki kecenderungan kebaikan, diantaranya: pertama, kebebasan. Kebebasan merupakan faktor yang menjadikan kapitalisme menjadi sistem yang tetap eksis. Kebebasan kapitalis tidak hanya didasari atas penghargaan hidup terhadap sesama, hal ini lebih disebabkan oleh kebebasan manusia akan lebih memberikan nilai tambah dalam produksi.

Kedua, meningkatkan produksi. Persaingan bebas akan mewujudkan tingkat produksi dan harga, persaingan akan mempertahankan terhadap keuntungan dan upah tingkat yang dapat diterima oleh pasar. Keseimbangan antara penawaran dan permintaan dipasar merupakan mekanisme yang diperlukan sebagai bentuk berjalannya ekonomi secara fair. Ketiga, profit motive. Keuntungan dalam sistem kapitalis adalah faktor penting, mencari keuntungan merupakan faktor pendorong bagi berjalannya mekanisme pasar (Sudarsono, 2002: 83).

\section{Sistem Ekonomi Sosialis}

Sosialisme secara umum dianggap sebagai obat untuk menghilangkan ketidaksamaan kesempatan akibat akumulasi distribusi kekayaan yang tidak adil. Ketika para reformis dengan penuh semangat memperjuangkan keadilan sosial dengan melihat adanya ketidakadilan dalam sistem ekonomi, maka mereka menuntut persamaan hak (Afzalurrrahman, 1995: 91). Filosofi sistem ekonomi sosialis adalah bagaimana secara bersama mendapatkan kesejahteraan. Perkembangan sosialisme dimulai dari kritik terhadap kapitalisme yang waktu itu kaum kapitalis disebut kaum borjuis mendapatkan legitimasi gereja untuk mengesploitasi buruh. Inilah yang membuat Karl Max mengkritik sistem Kapitalis, sebagai sistem ekonomi yang tidak sesuai dengan aspek kemasyarakatan. Filosofi Sosialis: Meratakan potensi yang suda jelas, berbeda, karena perbedaan inilah yang menyebabkan terjadinya 
kesinambungn kehidupan, manusia dianggap sama walaupun mempunyai potensi yang berbeda (Sudarsono, 2002: 87-87).

Sistem ekonomi sosialisme, mempunyai kecenderungan antara lain: pertama, pemilikan harta oleh Negara. Seluruh bentuk produksi, dan sumber pendapatan menjadi milik Negara, dan diatur untuk seluruh rakyat. Rakyat mendapatkan hasil kerjanya melalui pembagian yang sama yang dilakukan oleh Negara. Kedua, kesamaan ekonomi. Prinsip ini didasari atas kebutuhan minimal seseorang dalam hidupnya perhari. Kesamaan dalam memenuhi kebutuhan ekonominya didasarkan atas asumsi bahwa setiap orang mempunyai hak yang sama untuk mendapatkan pelayanan (Sudarsono, 2002: 87-88). Ketiga, disiplin politik. Untuk mencapai suatu tujuan, Negara secara keseluruhan diletakkan dibawah peraturan kaum buruh, yang mengambil alih semua aturan produksi dan distribusi. Kebebasan ekonomi serta hak pemilikan harta dihapus. Aturan yang dilakukan sangat ketat untuk mengefektifkan praktik sosialisme. Praktik sosialisme menunjukkan bahwa, sosialisme yang tidak memenuhi karakter sistem yang mamapu meningkatkan peran rakyat dalam berpartisifasi terhadap Negara (Sudarsono, 2002: 91).

Aspek-aspek kebaikan system ekonomi sosialis: petma, disediakannya kebutuhan pokok. Setiap warga Negara disediakan fasilitas kebutuhan pokoknya, termasuk penyediaan pekerjaan yang telah ditentukan Negara, orang cacat pisik dan mental dalam perlindungan dan perawatan Negara. Kedua, didasarkan perencanaan Negara. Seluruh pekerjaan dilakukan berdasarkan perencanaan, sehingga tidak akan terjadi kelebihan atau kekurangan produksi, spesifikasi masalah daerah disamakan dengan daerah lain dan masalah-masalah daerah direduksi oleh negara. Ketiga, produk dikelola oleh negara. Pemerintah sosialis lebih memfokuskan penyediaan sarana produksi yang berhubungan dengan kepentingan negara. Oleh karena itu penyediaan sarana produksi tidak pernah adil, karena lebih memprioritaskan kepentingan negara 
yang belum pasti sesuai dengan kepentingan rakyat, seperti penyediaan dan perawatan alat-alat perang (Sudarsono, 2002: 91).

Disisi lain, tentang kelemahan sistem ekonomi sosialis, diantaranya: pertama, sulit melakukan transaksi. Aktifitas jual beli sangat terbatas dilakukan dalam masyarakat sosialis, sebab harga ditentukan oleh negara. Oleh karena itu stabilitas perekonomian negara tidak terbuka, karena semua diatur oleh negara termasuk harga dipasaran, tidak berdasarkan dengan mekanisme pasar. Kedua, membatasi kebebasan. Kegiatan atau aktifitas ekonomi masyarakat dikondisikan dengan kehendak negara, dengan pola kerja sama setiap hari, hal semacam ini kurang memberi peluang pada masyarakat secara luas untuk memperluas wacana dan wawasan dalam hidupnya. Ketiga, mengabaikan pendidikan moral. Tujuan atau kepuasaan terhadap kebendaan, sangat diutamakan, pemikiran diarahkan pada hal-hal yang realistis, sehingga paham ateis dan materialistik sangat diutamakan, karena ekonomi sosialis memfokuskan pada optimalisasi produksi guna memenuhi target ekonomi yang telah direncakan (Sudarsono, 2002: 72).

\section{Sistem Ekonomi Islam}

Ciri penting sitem ekonomi Islam, adalah mengakui bahwa manusia memiliki kemerdekaan individu dan masyarakat. Islam menganggap kebebasan sebagai pondasi terhadap nilai-nilai martabat, dan martabat untuk seluruh umat manusia. Kebebasan yang membedakan manusia dengan makhluk lainnya, seorang individu memperoleh kebebasan sempurna dalam berfikir, bertindak dan memproleh mata pencaharian dalam negara Islam (Afzalurrrahman, 1995: 73). Memiliki kebebasan untuk memulai berorganisasi, mengatur dan memiliki perusahaan dalam batas kemampuannya, Kebebasan berikhtiar dalam perekonomian yang berdimensi keimanan pada pencipta.Ciri yang lain adalah pandangan Islam mengenai hak pemilikan individu. Islam mengakui hak-hak individu dan tidak melarang individu memiliki segala kekayaan yang diperoleh secara halal. Sebagai bukti kongkrit bahwa Islam mengakui 
kepemilikan hak pribadi dalam alQur'an ditegaskan: Q.S: 2/254 yaitu: Hai orang-orang beriman belanjakanlah dijalan Allah sebagian dari rezeki yang telah dianugrahkan kepadamu (Sudarsono, 2002: 74-75).

Islam sebagai suatu agama yang didasarkan pada Al-Qur'an dan Hadis, Islam juga memberikan tuntunan pada seluruh aspek kehidupan. Islam mengartikan agama tidak hanya yang berkaitan dengan spiritualitas maupun ritualitas, namun Islam merupakan serangkaian keyakinan, ketentuan, dan aturan serta tuntunan moral bagi setiap aspek kehidupan manusia. Lebih dari itu, Islam mengartikan agama sebagai sarana kehidupan yang melekat pada setiap aktivitas kehidupan, baik ketika manusia berhubungan Tuhan maupun berinteraksi dengan sesame manusia. Islam memandang keseluruhan aktivitas manusia dibumi ini sebagai sunatullah, termasuk didalamnya aktivitas ekonomi, ia menempatkan kegiatan ekonomi sebagai salah satu aspek penting untuk mendapatkan kemuliaan, olehnya itu kegiatana ekonomi, seperti halnya kegiatan lainnya perlu dikontrol dan dituntun agar sejalan dengan tujuan Syari'ah.

Islam memberikan tuntunan bagaimana seharusnya beribadah kepada Allah swt, serta bagaimana juga berinteraksi dalam kehidupan bermasyarakat (muamalah), baik dalam lingkungan keluarga, masyarakat, bernegara, berekonomi, dan sebagainya. Sebagai agama universal, Islam memiliki tanggung jawab terhadap kesejahteraan manusia, maka bagaimana manusia mempertahankan hidupnya, Islam juga telah memberikan tuntunan berekonomi secara Islami. Mislanya dalam kebijakan fiskal dilakukan dalam rangkan mengarahkan kondisi perekonomian untuk menjadi lebih baik dengan jalan mengubah penerimaan dan pengeluaran pemerintah. Kebijakan ini mirip dengan kebijakan monoter untuk mengatur jumlah uang yang beredar, namun kebijakan fiskal lebih menekankan pada pengaturan pendapatan dan belanja pemerintah.

Pemikiran ekonomi Islam dimulai sejak Muhammad saw, diangkat menjadi Rasul, beberapa 
kebijakan dikeluarkan yang berkaitan dengan masalah kemasyarakatan, selain masalah hukum/fikih, politik, juga masalah perniagaan atau ekonomi. Masalah ekonomi umat menjadi perhatian serius oleh Rasulullah saw, karena ekonomi merupakan pilar penjaga keimanan yang harus mendapat perhatian. Karena Kemiskinan dapat membawa orang pada kekafiran, salah satu upaya untuk mengentaskan kemiskinan merupakan salah satu bagiam dari kebijakan sosial yang dikeluarkan oleh Rasulullah saw.

$$
\text { Selanjutnya kebijakan }
$$

Rasulullah saw, menjadi pedoman oleh para penggantinya, seperti Abu Bakar, Umar bin Khattab, Usman bin Affan dan Ali bin Abi Thalaib dalam memutuskan persoalan-persoalan ekonomi, kemudian Al-Qur'an dan AlSunnah dijadikan sebagai landasan dan sumber teori oleh para khalifah, begitupula oleh para pengikutnya dalam menata kehidupan ekonomi negara (Chamid, 2010: 31-33). Meskipun perekonomian pada masa Beliau relativ sangat sederhana, tetapi Beliau telah menunjukkan prinsipprinsip yang mendasar bagi pengelolaan ekonomi, dengan karakter dan komitmen yang tinggi terhadap etika dan norma, serta perhatian yang serius terhadap penegakan keadilan dan pemerataan kekayaan. Kemudian usaha-usaha dibidang ekonomi harus dilakukan secara etis (bermatabat) dalam bingkai syariat Islam, dan sumberdaya manusia tidak boleh menumpuk pada segelintir orang, melainkan harus beredar untuk kesejahteraan bagi seluruh umat manusia. Olehnya itu pasar mempunyai peran penting bagi mekanisme ekonomi, dan pemerintah bersama masyarakat berperan aktif dalam mewujudkan kesejahteraan dan menegakkan keadilan. Kegiatan ekonomi pasar relatif menonjol pada masa itu, untuk menjaga agar mekanisme pasar tetap berada dalam bingkai etika dan moralitas Islam, maka Rasulullah saw, mendirikan AlHisbah (yaitu Institusi yang bertugas sebagai pengawas pasar) atau market controller. Membentuk Baitul Maal, sebagi institusi yang bertindak sebagai pengelola keuangan Negara. Baitul Maal memegang peranan yang sangat penting dalam perekonomian, 
termasuk melakukan kebijakan yang bertujuan untuk kesejahteraan masyarakat.Sehingga Rasulullah saw, mengawali pembangunan di Madinah, tanpa sumber keuangan yang pasti, sementara distribusi kekayaan juga mengalami ketimpangan, kaum Muhajirin yang tidak memiliki kekayaan, karena mereka meninggalkan hartanya di Makkah, kemudian Rasulullah saw, mempersaudarakan antara kaum Muhajrin dan kaum Anshar dengan kebijakan ini maka terjadi distribusi kekayaan pada masyarakat. Kebijakan ini sangat penting sebagai strategi awal pembangunan di Madinah. Selanjutnya untuk memutar roda perekonomian, Rasulullah saw, mendorong kerjasama usaha di antara anggota masyarakat dengan cara, Muzaarah, Mudharabah, Musaqad dan lainlain, dengan cara ini terciptalah peningkatan produktifitas (Pusat Pengkajian dan Pengembangan Ekonomi Islam, 2014: 97-99).

Lahirnya kebijakan fiskal dalam dunia Islam dipengaruhi oleh banyak faktor, fiskal merupakan bagian dari instrument ekonomi publik. Untuk itu faktor-faktor seperti sosial budaya, dan politik termasuk didalamnya. Tantangan Rasulullah saw sangat besar dimana beliau dihadapkan dengan kehidupan yang tidak menentu baik dari kelompok internal maupun kelompok eksternal. Kelompok internal yang harus diselesaikan oleh Rasulullah saw. Yaitu bagaimana menyatukan antara kaum Anshar dengan kaum Muhajirin paska hijrah dari Makkah ke Madinah. Sementara tantangan dari kelompok eksternal adalah bagaimana Rasulullah saw, mampu mengimbangi rongrongan dan serbuan dari kaum kafir Qurays. Disisi lain Rasulullah saw. harus melakukan pembenahan disektor ekonomi. Dalam kondisi yang tidak menentu tersebut, kondisi alam yang tidak mendukung, ditamba lagi kondisi ekonomi masyarakat yang masih lemah, maka salah satu sumberdaya alam yang bisa diandalkan adalah pertanian. Karena sektor pertanian yang menjadi satusatunya harapan untuk dikelola dengan cara-cara tradisional sehingga terkesan apa adanya. Banyaknya problematikan yang dihadapi oleh Beliau, sehingga kebijakan yang 
dibuatnya sedapat mungkin dapat menguntungkan oleh semua pihak.

Segala kegiatan yang dilakukan oleh Rasulullah saw, diawal masa pemerintahan dilakukan dengan dasar keikhlasan, karena dianggap sebagai kegiatan dakwa dalam Islam. Ada dua hal penting yang telah dijalani dan diubah oleh Rasulullah saw pada waktu itu: Pertama, adanya penomena unik yakni, bahwa Islam telah membuang sebagian besar tradisi, ritual, norma-norma, nilai-nilai, tandatanda, dan patung-patung dari masa lampau, dan memulai dengan yang baru terhadap Negara yang bersih (Nabahan, 2000: 3). Semua peraturan dan regulasi disusun berdasarkan $\mathrm{Al}$ Qur'an, dengan memasukkan karakteristik dasar dari Islam, seperti : persaudaraan, persamaan, kebebasan dan keadilan. Kedua : Negara baru saja dibentuk tanpa menggunakan sumberdaya keuangan ataupun moneter, karena Negara yang baru terbentuk ini sama sekali tidak diwariskan harta, maupun persediaan dari masa lampau, sementara sumber keuangan belum ada. Oleh karena itu, peletakan dasar-dasar sistem keuangan yang dilakukan oleh Rasulullah saw, merupakan langkah yang sangat signifikan, dan spektakuler pada masa itu, sehingga Islam sebagai sebuah agama dan Negara dapat berkembang dalam jangka waktu yang relativ singkat.

Sistem ekonomi yang diterapkan oleh Rasulullah saw, berdasarkan dari prinsip-prinsip Qur'ani yang merupakan sumber utama ajaran Islam, telah menetapkan berbagai aturan sebagai hidayah (petunjuk) bagi umat manusia dalam melakukan aktifitas disetiap aspek kehidupannya, termasuk bidang ekonomi. Dalam pandangan Islam kehidupan manusia tidak bisa dipisahkan dari kehidupan ruhaniyah dan kehidupan jasmaniah, dengan kata lain, Islam tidak mengenal kehidupan yang hanya berorientasi pada akhirat tanpa memikirkan kehidupan duniawi, ataupun sebaliknya hanya memikirkan materi duniawi tanpa memikirkan kehidupan akhirat. Namun demikian, kehidupan duniawi tidak hanya penuh dengan kebaikan, tetapi juga penuh dngan kejahatan, yang setiap saat dapat menjerumuskan manusia dalam 
kesalahan dan dosa. Dalam rangka mengembang amanah sebagai khalifahNya, manusia diberi kebebasan untuk mencari nafkah yang sesuai dengan hukum yang berlaku serta dengan cara yang adil, hal ini merupakan salah satu kewajiban asasi dalam Islam. Walaupun pada dasarnya Islam mengakui kepemilikan pribadi,alatalat produksi, barang dagangan ataupun perdagangan. Islam hanya melarang perolehan kekayaan melalui cara-cara yang illegal atau tidak normal. Islam sangat menentang setiap aktivitas ekonomi yang bertujuan melakukan penimbunan kekayaan atau mengambil keuntungan yang tidak layak dari kesulitan orang lain. Olehnya itu, menumpuk harta serta tidak menggunakannya untuk berbagai tujuan kebutuhan yang bermanfaat bagi umat manusia, merupakan perbuatan yang tidak diperkenangkan dalam ajaran Islam, karena menjadikan seseorang kaya raya, sementara kepentingan dan kesejahteraan orang lain dan masyarakat terampas. Dalam kerangka yang sama, penimbunan kebutuhan bahan-bahan pokok juga dilarang,
Orang yang melakukan penimbunan kekayaan atau barang merupakan sebuah tindakan kriminal terhadap masyarakat, dan layak untuk mendapatkan hukuman, baik di dunia maupun diakhirat.

Pada surah al-Hasyr ayat 7 , Allah swt. menjelaskan tentang aspek lain tentang pelarangan penimbunan kekayaan. Menurut para Muffisirin, ayat ini berkaitan dengan wilayah Bani Nadhir yang jatuh ketangan kaum muslimin tanpa melalui peperangan atau pertempuran. Semua aset yang ditinggalkan oleh Bani Nadhir dipandang sebagai harta Fay'i Negara, dan orang-orang yang berhak menerimanya telah ditentukan dalam Al-Qur'an yaitu :Kaum Krabat, anak-anak Yatim,Orang Miskin, dan para Musafir. Dalam hal ini, Al-Qur'an memberikan penjelasan tentang rasionalisasi terhadap ketentuan di atas, maksudnya agar harta itu jangan hanya berputar diantara orang-orang kaya. Sehingga penumpukan dan penimbunan kekayaan oleh sebagaian individu maupun kelompok tidak diperbolehkan (Nabahan, 2000: 29). Islam memandang bahwa setiap orang 
mempunyai hak penuh untuk dapat memiliki penghasilan, atau memperoleh harta kekayaan secara legal, sehingga dapat menunaikan kewajiban agamanya dengan baik dan sempurna.Al-Qur'an secara tegas telah menetapkan besarnya bagian untuk setiap ahli waris, termasuk bagian dari seorang kategori Kalalah (yang tidak mempunyai anak dan orang tua atau sebatang kara.termasuk yang kategori janda. Ide yang mendasari keseluruhan sistem warisan dalam Al-Qur'an, adalah untuk pendistribusian kepemilikan atau kekayaan seseorang kepada orang lainnya, maksudnya semakin banyak orang yang menerimanya akan semakin baik pula implikasinya bagi kehidupan manusia secara keseluruhan.

Begitu pula Al-Qur'an memerintahkan kepada seseorang yang memiliki kekayaan yang berlimpah, agar berwasiat sebelum meninggal dunia, dari keseluruhan jumlah kekayaannya, dengan ketentuan bahwa yang diperbolehkan hanya sebanyak sepertiga, dan sisanya yang berjumlah dua pertiga harus dibagikan kepada ahli warsinya sesuai dengan ketentuan Syariat Islam.

Berdasarkan pandangan yang paling prinsip tentang status manusia dipersada bumi ini, bahwa Islam dengan tegas dan keras melarang segala bentuk praktik Ribawi atau Bunga Uang, pendapat atau pemikiran yang menyatakan bahwa pendapatan yang diproleh dengan cara-cara Ribawi adalah sah, jelas merupakan pendapat yang keliru dan menyesatkan, karena praktik-praktik Ribawi merupakan bentuk eksploitasi yang nyata, dimana Syariat Islam sangat melarang secara tegas tentang bentuk eksploitasi yang nyata, apapun bentuknya, apakah dilakukan oleh penjual dengan pembeli, majikan terhadap karyawannya, laki-laki terhadap wanita, atau oleh atasan terhadap bawahannya (Rifa'i, Zuhri, dan Salomo, 1985: 187). Ketika melarang segala bentuk Peraktik ribawi, disisi lain Islam memperkenalkan sebuah konsep baru yang dapat mengubah cara pandang umat Islam. Konsep tersebut berupa perintah mengeluarkan sedekah, baik yang bersifat wajib maupun yang sunnah. 
Rasulullah saw, memerintahkan kepada kaum muslimin yang memiliki kelebihan harta untuk membelanjakan sebagaian hartanya dijalan Allah saw, yaitu yang tidak mengharapkan imbalan materi duniawi, tetapi hanya mengharapkan ridha Allah swt semata, seperti tolong-menolong, pemberian makanan, serta pemberian pinjaman kepada sanak saudara yang miskin, para tawanan, musafir, muhajirin yang miskin, para pengutang yang tidak bisa lagi melunasi hutangnya. Dalam AlQur'an pinjaman yang semacam ini disebut Allah sebagai pinjaman yang ditujukan kepada Allah swt.

Islam sebagai suatu Agama yang didasarkan pada Al-Qur'an dan Sunnah, Islam juga memberikan tuntunan pada seluruh aspek kehidupan. Islam sebagai agama, yang mengajarkan tidak hanya yang berkaitan dengan spritualitas maupun ritualitas semata, namun Islam merupakan serangkaian keyakinan, ketentuan, dan aturan serta tuntunan moral bagi setiap aspek kehidupan manusia. Lebih dari itu, Islam mengartikan Agama sebagai sarana kehidupan yang melekat pada setiap aktivitas kehidupan, baik ketika manusia berhubungan dengan Tuhan maupun pada saat beriteraksi dengan sesama manusia. Islam memandang keseluruhan aktivitas manusia dibumi ini sebagai sunatullah, termasuk di dalamnya aktivitas ekonomi, ia menempatkan kegiatan ekonomi sebagai salah satu aspek penting untuk mendapatkan kemuliaan, dan karenanya kegiatan ekonomi, seperti kegiatan lainnya perlu dikontrol dan dituntun agar sejalan dengan tujuan Syari'at.

Islam memberikan tuntunan, bagaimana seharusnya beribadah kepada Allah swt, serta bagaimana pula berinteraksi dalam kehidupan bermasyarakat (ber-mu'amalah) baik dalam lingkungankeluarga, masyarakat, brnegara, berekonomi, dan lain sebagainya. Sebagai agama universal, Islam memiliki tanggung jawab terhadap kesejahteraan manusia, maka bagaimana manusia mempertahankan hidupnya, Islam juga telah memberikan tuntunan berekonomi secara Islami.

Dalam usahanya meningkatkan kesejahteraan umat Islam, Abu Bakar 
Ash-Shiddiq, melaksanakan berbagai kebijakan ekonomi seperti yang telah diperaktikkan Rasulullah saw, Ia sangat memperhatikan keakuratan penghitungan zakat sehingga tidak terjadi kelebihan atau kekurangan pembayarannya. Hasil pengumpulan zakat tersebut dijadikan sebagai pendapatan Negara yang disimpan dalam Baitul Mal, untuk langsung didistribusikan seluruhnya kapada kaum Muslimin hingga tidak ada yang tersisa (Djazuli dkk, 2002: 1l).

Selama masa pemerintahan Abu Bakar Ash-Shidiq harta baitul mal tidak pernah menumpuk dalam jangka waktu yang lama karena langsung didistribusikan kepada kaum muslimin, bahkan ketika Abu Bakar Ash-Shidieqy wafat, hanya ditemukan satu dirham dalam perbendaharaan Negara. Seluruh kaum Muslimin diberikan bagian yang sama dari hasil pendapatan Negara. Apabila pendapatan meningkat, seluruh kaum muslimin mendapat manfaat yang sama, dan tidak ada seorang pun yang dibiarkan dalam kemiskinan. Kebijakan tersebut beriimplikasi pada peningkatan pendapatan secara nasional. Di samping memperkecil jurang pemisah antara.orang-orang kaya dengan yang miskin.

Sistem ekonomi Islam, tidak hanya menganjurkan kesamaan ekonomi, tetapi mendukung dan menggalakkan kesamaan sosial. Karena kesamaan sosial menjadikan masyarakat merasa mempunyai peluang untuk menjadi yang terbaik, dan mendorong upaya pemberdayaan diri. Dari kesamaan sosial akan membentuk keharmonisan dalam kehidupan sehari-hari.

Di antara keunggulan sistem ekonomi Islam: pertama, adanya jaminan sosial. Sistem ekonomi Islam, negara mempunyai tanggungjawab untuk mengalokasikan sumber daya untuk meningkatkan kesejahteraan rakyat. Dimasa Khalifah Umar, tanah yang tidak dikelola pemiliknya selama tiga tahun diambil oleh Negara untuk diberikan kepada orang miskin yang mampu mengelolanya, maksudnya, Islam menjamin kehidupan masyarakat untuk mendapatkan kesejahteraan. Kedua, distribusi kekayaan. 
Pemilikan kekayaan dianggap sebagai amanah, sehingga tidak terjadi penumpukan harta pada kelompok masyarakat tertentu, sehingga Islam menganjurkan agar mendistribusikan kekayan seperti dengan adanya ketentuan untuk mengeluarkan zakat, serta berupaya mensejahterakan individu dan masyarakat dengan konsep tolong-menolong kepada sesama kaum muslimin.

\section{Faktor-faktor yang Mempengaruhi} Keragaman Sistem Ekonomi

\section{Latar Belakang Sejarah dan Ideologi}

Sistem ekonomi terbentuk dari pengalaman masa lalu negara bersangkutan dalam mengelola negaranya. Bila masa lalu negara tersebut berhubungan dengan usaha untuk memisahkan diri dari dominasi negara yang memiliki sistem kapitalis, maka timbul kecenderungan negara tersebut akan menggunakan sistem sosialis, misalnya : Vietnam, Korea Utara. Sedangkan negara-negara yang diberikan kemerdekaan oleh negara yang bermashab kapitalis, seperti Kanada,Australia, Selandia Baru dan
Malaysia.Cenderung menggunakan sistem kapitalis termasuk Indonesia. Berbicara masalah ekonomi pada masa Rasulullah saw, akan ditemukan sebuah kegiatan ekonomi yang sangat sederhana, yang tidak ditemukan diera ekonomi modern seperti saat ini. Pendapat penduduk di zaman Rasulullah sangat minim begitu pula pendapat negara, di awal masa pemerintahan beliau di Kota Madinah. Umumnya masyarakat Arab pada masa Rasulullah saw, masih mengandalkan pertanian dan peternakan. Sebagai pemimpin negara bersama dengan rakyatnya membangun sebuah negara yaitu Kota Madinah dengan suka rela, karena pendapatan negara boleh dibilang sangat kecil. Pada masa inilah Rasulullah saw, meletakkan dasardasar pemikiran dan konsep ekonomi Islam yang berdasarkan Al-Qur'an dan Al-Sunnah, yang berperinsipkan dengan keadilan dan moral.

Rasulullah saw, membangun sebuah negara Islam, ekonomi adalah salah satu faktor utama, membangun sistem ekonomi yang baik Rasulullah saw, membutuhkan kebijakan dan strategi yang jitu untuk mendongkrat 
perekonomian negara, sehingga Rasulullah saw, mempunyai kebijakan fiskal dalam mengatur negaranya, Dengan kebijakan-kebijakan inilah yang berdasarkan Al-Qur'an dan AlSunnah, dengan perinsip akhlak,moral, dan keadilan, sehingga negara dapat memiliki sumber pendapat Negara yang tetap. Baik dalam bentuk pemasukan primer maupun sekunder.

Pendapatan negara di masa Rasulullah saw, seperti Ghanimah (harta rampasan perang), Jizya, zakat dan wakaf, dan sebagainya, pendapatan inilah yang membuat pertumbuhan perekonomian negara membaik, kemudian dengan pemikiran ekonomi yang telah di tanamkan Rasulullah saw, yang berdasarkan pada prinsip keadilan, keterbukaan kejujuran, dan amanah, kemudian diikuti oleh para Shahabatnya, kemudian berkembang sampai saat ini.

Perkembangan sistem ekonomi Islam, adalah suatu yang tidak dapat dipisahkan dari perkembangan sejarah Islam. Walaupun sejumlah literatur tidak secara implisit menyebutkan keberadaan pemikiran ekonomi Islam, tetapi hal ini diakibatkan oleh perkembangan ekonomi Islam tidak dipisahkan dari perkembangan sosial kemasyarakatan.

\section{Luas dan Letak Geografis}

Letak antara suatu negara dengan negara lainnya sangat mungkin mempengaruhi sistem ekonomi, karena letak suatu negara dapat menimbulkan pengkondisian antara negara yang bertetangga untuk menggunakan kebijakan yang saling mendukung untuk mempermudah terjadinya hubungan ekonomi. Hubungan antara dua negara atau lebih tidak akan terjadi jika tidak memiliki kesamaan sistem ekonomi diantara negara-negara yang bersangkutan.

\section{Tingkat Pembangunan}

Negara berkembang dengan tingkat pendapatan yang rendah perlu dilindungi, dalam mengelola faktor produksinya, oleh karena itu, pemerintah harus bertanggungjawab atas penyediaan sarana pendukung optimalisasi proses produksi, keteraturan mekanisme barang dan jasa, sangat membantu menyediakan infrastruktur penunjang pengelolaan faktor produksi. 


\section{Keterbukaan}

Konsep ekonomi terbuka menjadikan sistem ekonomi suatu negara berubah menjadi sistem ekonomi bebas, dengan tidak mengakui adanya batas antara suatu negara,dan antara benua, sehingga sistem ekonomi terbuka, maka setiap negara mempunyai peran penting untuk menyediakan fasilitas pendukung agar mekanisme pasar dapat berjalan dengan baik.

\section{Sistem Politik}

Sistem politik yang baik adalah memberikan perhatian untuk memperjuangkan kepentingan rakyat dengan memberiken kebebasan yang terkendali, untuk menentukan kebijakan ekonomi seperti apa yang sesuai dengan budaya yang telah berkembang dan dilaksanakan secara baik dengan penuh rasa tanggungjawab (Sudarsono, 2002: 70-71).

\section{Solusi Sistem Ekonomi Islam Dalam} Mewujudkan Tujuan Sosial Ekonomi

1. Menjadikan Islam Sebagai Way of Life

Menjadikan Islam sebagai way of life dengan tuntunan Al-Qur'an yang mengandung aspek dan dimensi kehidupan, serta menjadikan Hadis sebagai action dalam ibadah ritual dan sosial. Jika Islam dijadikan sebagai pandangan hidup, maka kehidupan itu adalah anugerah Allah swt. sehingga perlu dimanfaatkan sebai-baiknya.

Membentuk pola hidup yaitu menjaga kualitas diri,akal pikiran, harta benda, serta keturunan dan kekayaan. Kemudian etika hidup, yaitu perpaduan antara ibadah ritual dan ibadah sosial, menjunjung tinggi nilainilai akhlak dalam pergaulan hidup (Yafie, 2003: 1-4).

\section{Membangun Tatanan Ekonomi di} atas Landasan Aqidah dan Syariah Membangun dinamika perekonomian Islam yang berpijak di atas landasan aqidah dan syariah, dengan melakukan keadilan dan kebajikan sebagai variable indicator untuk memeproleh kepuasan, keharmonisan dan inteaksi ekonomi yang dapat memberi kepuasan terpadu. Dengan keharmonisan mengantar kehidupan yang dapat membahagiaan serta menumbuhkan kehormatan hidup di masyarakat. 
3. Mengakomodari Keimanan dan Usaha untuk Bekerja

Membangun kesadaran untuk mengurangi tingkat kemiskinan, mengembangkan potensi kaimanan dengan landasan untuk meningkatkan kualitas hidup dengan berupaya membangun usaha ekonomi, bekerja sebagai refleksi dari keimanan atau ibadah ritual. Membangun jamaah silaturrahim serta menggerakkan kesadaran kolektif ummat untuk bangkit dari keterpurukan ekonomi.

\section{Menyusun Pola Kerja yang Strategik}

Menggerakkan pola kerja yaitu: produksi, distribusi dan konsumsi, diatas pijakan aqidah Islam yang berorientasi pada manfaat. Memperlakukan tenaga kerja sebagai partner, sekaligus sebagai pelaku yang menentukan kerja dan hasil pekerjaan (out put). Menghindari dari perguluman riba dan membangun sistem bagi hasil sebagai pola strategic untuk mengurangi tingkat kemiskinan.

5. Menggerakkan Lembaga-lembaga Ekonomi Islam

Memplopori gerakan sadar Zakat,Infak dan Shadaqah, yang dijadikan sebagai alat ekonomi, sehingga mengandung metode dan fleksibilitas tinggi terhadap Zakat,Infak dan Shadaqah, mendorong motivasi dan kreasi masyarakat dalam pemilikan dan penggunaan harta kekayaan, karena Zakat, Infak dan Shadaqah, memiliki aspek metode pelaksanaan yang terkonsentrasi pada aspek konsumtif dan produktif. Menanamkan kepercayaan pada lembaga-lembaga keuangan Islam untuk mengelola dana investasi dengan tujuan membangun kerangka bangunan ekonomi Islam yang kokoh yang dibangun di atas sikap saling membantu dan dihiasi dengan kualitas kejujuran (Basalamah, 2003: 39-47).

E. Penutup

Sistem ekonomi kapitalis dipengaruhi oleh semangat untuk mendapatkan keuntungan semaksimal mungkin dengan sumber daya yang terbatas. Ciri dari sistem ini adalah adanya kebebasan memiliki harta perorangan, adanya persaingan bebas. Sedangkan sistem ekonomi sosialis dipengaruhi oleh filosofi bagaimana secara bersama mendapatkan kesejahteraan. Kecenderungan dalam 
sistem ini adalah: pemilikan harta oleh pemerintah (negara), adanya kesamaan ekonomi. Sedangkan aspek positifnya, disedikannya kebutuhan pokok oleh negara produksi dan lalulintas ekonomi direncanakan oleh negara.

Sistem ekonomi Islam memiliki ciri khusus yaitu: bahwa Islam mengakui kebebasan manusia untuk berkreasi dalam ekonomi diatas landasan tauhid, demikian pula bahwa kekayaan perlu didistribusikan dengan adanya hak orang lain, yaitu Fakir, Miskin dll sbg. Sehingga dalam Islam ada kewajiban untuk berbagi melalui Zakat, Infaq dan Shadaqah.

Faktor yang mempengaruhi lahirnya keragaman sistem ekonomi antara lain adalah: latar belakang sejarah serta ideologi Negara, luas dan letak geografis, tingkat pembangunan serta adanya politik pintu terbuka untuk menjalin kerjasama dengan negara lain, serta sistem politik yang dianut oleh negara tersebut.

Solusi sistem ekonomi Islam dalam mewujudkan tujuan sosial ekonomi, menjadikan Islam sebagai Way of live, membangun kesadaran umat secara kolektif dengan jalinan silaturrahmi ekonomi yang kokoh, mengakomodasi nilai-nlai keimanan dalam setiap aktifitas ekonomi, menyusun pola kerja yang strategic serta memberdayakan (memberi kepercayaan) pada lembaga-lembaga keuangan Islam untuk mengelola dana investasi dari seluruh kaum muslimin diatas saling percaya dan kejujuran.

\section{DAFTAR PUSTAKA}

Afzalurrahman, Muhammad. Encylopedia Of Seerah. Volume III, Buku III, diterjemahkan oleh Dewi Nurjuliani dkk. Muhammad Sebagai Seorang Pedagang. Cet.I, Jakarta: Swarna Bhumy, 1995

An-Nabahan, M. Faruq. Sistem Ekonomi Islam: Pilihan Setelah Kegagalan Sistem Kapitalis dan Sosialis. Yogyakarta: UII Press, 2000

Husai \& Susanto B. Menggagas Konsep Ekonomi Syariah. Cet.I, Makassar: UMITHOHA, 2003

Lihat Pusat Pengkajian dan Pengembangan Ekonomi Islam. Ekonomi Islam. Jakarta: PT.Raja Grafindo Persada, 2014

Quraish, M.Shihab. Secercah Cahaya Ilahi. Cet.III, Bandung: Mizan, 2002 Membumikan Al-Qur'an. Cet.XXIV, Bandung: Mizan, 2002 
Ramly, H.Mansyur. Pengembangan Teori Ekonomi Dalam Perpektif Islam. UMI, Ujungpandang, 1997

Sudarsono, Heri. Konsep Ekonomi Islam Suatu Pengantar. Cet.I, Jogyakarta: Ekonisia, 2002

H.A. Djazuli dan Yadi Janwari. Lembagalembaga Perekonomian Umat (Sebuah
Pengenalan). Cet.I, Jakarta: PT. Raja Grafindo Persada, 2002

Moh.Rifa'i, Moh.Zuhri, Salomo, Terjamah Khulashah Kifayatul Akhyar. Cet.I, Semarang: CV.Toha Putra Semarang, 1982 